\title{
Capital Budgeting Practices: A Survey of Croatian Firms
}

\section{Lidija Dedi and Silvije Orsag}

\section{Abstract}

This paper reports the results of a mail survey of capital budgeting practices among Croatian firms and compares the results with those from similar studies in the USA, UK, Sweden, and other European countries. It is based on a questionnaire sent to 200 firms selected from 400 of the best Croatian firms (special edition of «Privredni vjesnik) and to 34 banks from a ranking of Croatian banks (special edition of «Privredni vjesnik). The response rate was 25,21\%. The goal of the empirical survey was to determine the present application of quantitative capital budgeting methods, cost of capital and cash flow estimation, risk analysis and application of a real options approach in capital budgeting practices in Croatian firms. This is the first empirical survey of Croatian capital budgeting practices that has been undertaken.

JEL: G31

DOI: $10.2478 / v 10033-007-0016-y$

\section{Introduction}

This empirical survey was undertaken with a selected sample of shareholding firms and other legal forms of business organization in Croatia. The goal of the empirical survey was to determine the present application of quantitative capital budgeting methods, cost of capital and cash flow estimation, risk analysis and application of a real options approach. The observed units included real economic entities structured by the industry, the size of the revenue, number of employees, and ownership. The specific industry was banking. The 234 questionnaires were sent to a selected sample of the public and private share holding companies and other forms of business organizations in financial and non-financial sectors. The survey was undertaken with these sample entities because their success represents the current level of use for capital budgeting applications. From the rankings of the 400 best Croatian firms (special edition of «Privredni vjesnik) 200 non-financial firms were selected and questionnaires sent to their financial managers. Because of the dominant position of banks in the financial industry, banks were seen to best represent this sector, and questionnaires were sent to 34 general managers of the highest-ranked banks in Croatia (special edition of «Privredni vjesnik). The questionnaire was divided into two groups of questions: the first group consisted of general questions about the firm, while the second group concerned its capital budgeting process.

\section{Profile of the Surveyed Firms}

The survey had a response rate of $25 \%$ for the selected non-financial firms (50 out of 200). The response rate from the banks was $26,47 \%$ (9 out of 34 ). The total response rate was $25,21 \%$ (29 out of 234).

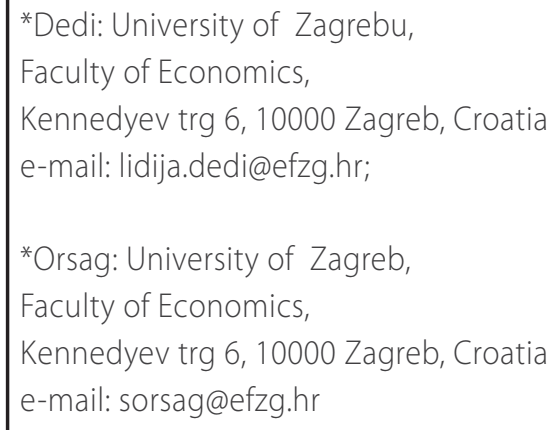


The firms that responded belong to different industries (Figure 1). Forty-one percent of the firms were manufacturers. Two percent of the firms were involved in manufacturing and tourism, and three percent involved in manufacturing, transportation and energy. The non-manufacturing firms were spread across other industries, including transportation and energy (8\%), finance and banking (15\%), tourism (7\%), pharmaceuticals (5\%), or other industries (19\%).

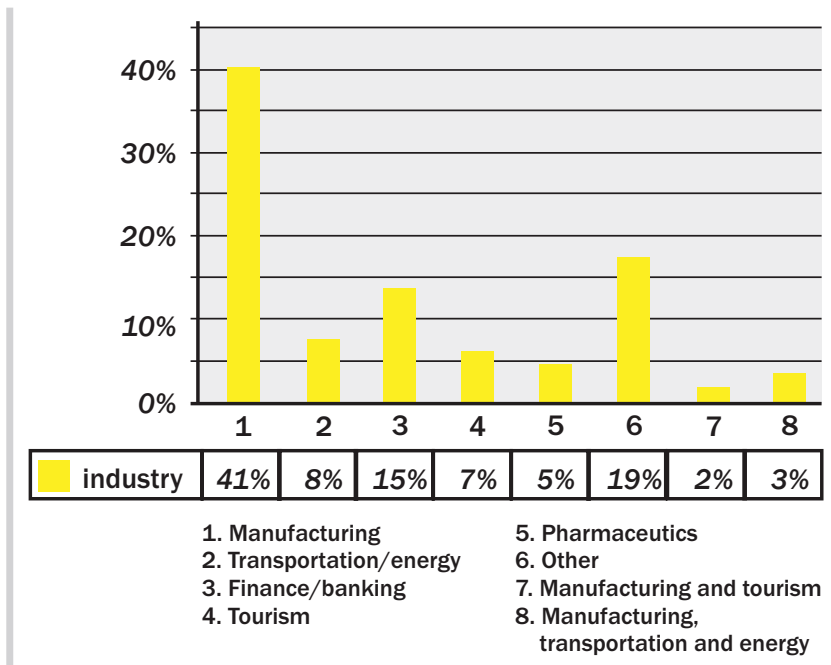

Figure 1.

Industry

Figure 2 presents the size of the firms according to total revenue. $24 \%$ of the sample firms have a total revenue of less than 250 million kuna, 17\% have a total revenue from 250 - 500 million, 17\% have a total revenue from 500 - 750 million, 8\% have a total revenue from 750 - 1.000 million, and 34\% have a total revenue of more than 1 billion kuna.

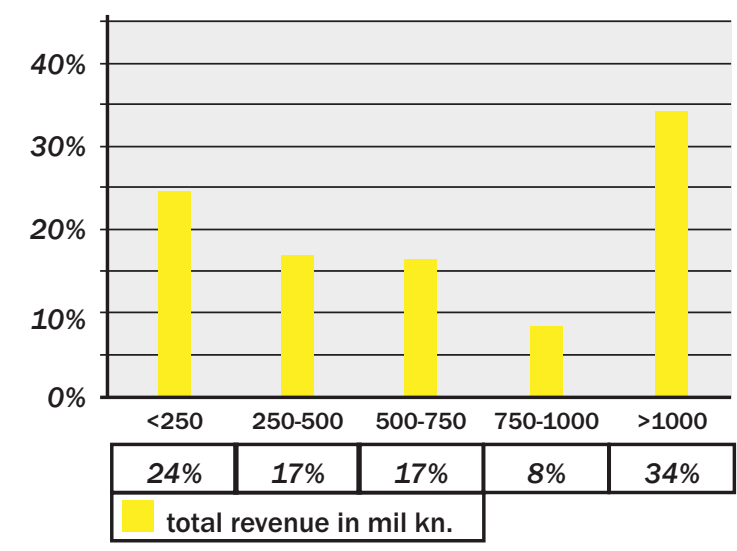

Figure 2.

Total revenue in millions kuna

According to their number of employees, $41 \%$ of the sample firms have less than 500 employees, 17\% of firms have from 500 - 1.000 employees, 20\% have from 1.000 - 3.000 employees, $7 \%$ have from 3.000 - 5.000 employees, and $15 \%$ of the firms have more than 5.000 employees (Figure 3).

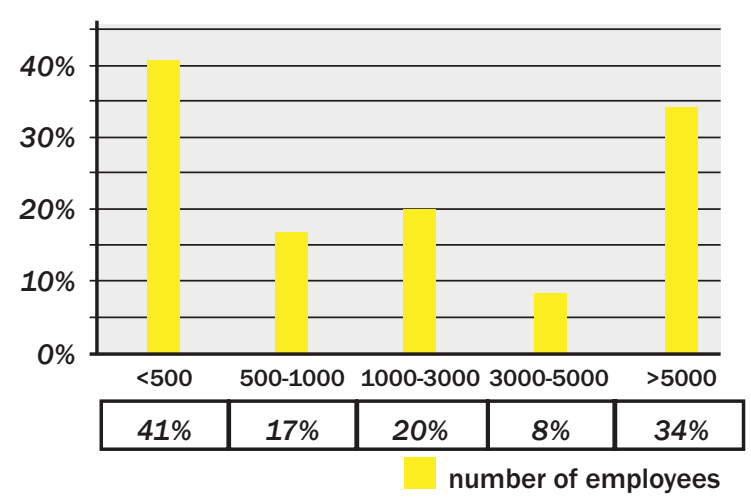

Figure 3.

Firms according to the number of employees

According to their ownership, of the 59 firms responding to the survey, 69\% are organized as a corporation (share holding company), $19 \%$ as limited liability companies, while 12\% are state owned firms.

Figure 4 shows foreign sales as a percentage of total revenue. $37 \%$ of the sample firms realize foreign revenues of $1-25 \%$, $12 \%$ realize 25 - 50\%, 19\% realize more than 50\%, and 15\% of the sample firms realize only domestic revenues. $17 \%$ of the firms did not respond to this question.

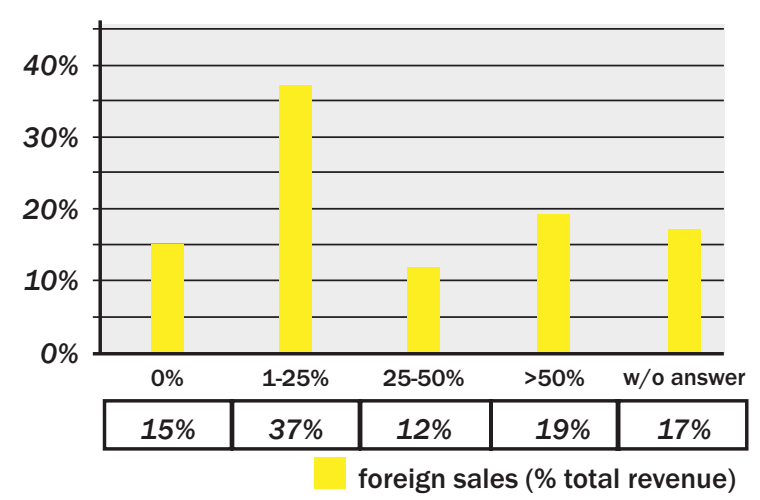

Figure 4.

Foreign sales ( $\%$ of total revenue)

\section{Capital Budgeting Practices}

The survey showed that $56 \%$ of the sample firms have departments for long-term investments, $42 \%$ do not have departments for long-term investments, while $2 \%$ did not answer the question. $49 \%$ of the firms have separate departments for project forming and analysis, $49 \%$ do not have separate departments for project forming and analysis, while $2 \%$ did not answer. Regarding a formal Capital Budgeting Manual, just 25\% of the firms have a Capital Budgeting Manual, while 75\% do not. The firms that have a Capital Budgeting Manual indicated the following items defined in the Manual (Table 1). 


\begin{tabular}{|c|c|c|c|c|c|c|c|c|c|c|c|c|c|c|}
\hline Items defined in Manual & & & & & & & & & & & & & & \\
\hline Investment idea candidates & $\mathrm{x}$ & $\mathrm{x}$ & $\mathrm{x}$ & $\mathrm{x}$ & $\mathrm{x}$ & $\mathrm{x}$ & $\mathrm{x}$ & $\mathrm{x}$ & $\mathrm{X}$ & & & & $\mathrm{X}$ & $\mathrm{x}$ \\
\hline Gathering data process & $x$ & $x$ & $x$ & $x$ & $x$ & $x$ & $x$ & $x$ & $x$ & $x$ & $x$ & $x$ & $x$ & \\
\hline Cash flows forming & $x$ & $x$ & $x$ & $x$ & $x$ & $x$ & $x$ & $x$ & & $x$ & $\mathrm{x}$ & $x$ & & \\
\hline Cost of capital & $x$ & $x$ & $x$ & $x$ & $x$ & $x$ & $\mathrm{x}$ & $\mathrm{x}$ & $\mathrm{x}$ & $\mathrm{x}$ & $\mathrm{X}$ & $\mathbf{x}$ & & \\
\hline Project risk & $x$ & $x$ & $x$ & $x$ & $x$ & $x$ & $x$ & $x$ & $x$ & $x$ & $\mathrm{x}$ & & & \\
\hline Decision making rules & $x$ & $x$ & $x$ & $x$ & $x$ & $x$ & $x$ & & $x$ & & $\mathrm{x}$ & $x$ & & $\mathrm{X}$ \\
\hline Investment evaluation and ranking & $\mathrm{x}$ & $\mathrm{x}$ & $\mathrm{x}$ & $\mathrm{x}$ & $\mathrm{x}$ & & $\mathrm{x}$ & & $\mathrm{x}$ & & & & $\mathrm{x}$ & $\mathrm{x}$ \\
\hline
\end{tabular}

Table 1.

Capital Budgeting Manual define

\subsection{Capital Budgeting Methods}

One of the goals of this survey was to determine the capital budgeting methods most commonly used by Croatian firms. The respondents were asked to score how frequently they use different capital budgeting techniques (i.e., sometimes, often, always, never). When evaluating investment projects, Croatian firms use a variety of capital budgeting techniques. Their responses are summarized in Exhibit 1.

\begin{tabular}{|c|c|c|c|c|}
\hline & $\begin{array}{l}\text { Some } \\
\text { times }\end{array}$ & Often & Always & Never \\
\hline Internal Rate of Return & $6(10 \%)$ & 7 (12\%) & 35 (59\%) & $11(19 \%)$ \\
\hline Payback Period & $5(8 \%)$ & $11(19 \%)$ & $33(56 \%)$ & $10(17 \%)$ \\
\hline Net Present Value & $6(10 \%)$ & $14(24 \%)$ & $25(42 \%)$ & $14(24 \%)$ \\
\hline Discounted Payback Period & $14(24 \%)$ & $8(14 \%)$ & $16(27 \%)$ & $21(36 \%)$ \\
\hline Profitability Index & $5(8 \%)$ & $14(24 \%)$ & $13(22 \%)$ & $27(46 \%)$ \\
\hline Annuity Method & $13(22 \%)$ & $6(10 \%)$ & $6(10 \%)$ & $34(58 \%)$ \\
\hline Modified Int. Rate of Return & $15(25 \%)$ & $3(5 \%)$ & $2(3 \%)$ & $39(66 \%)$ \\
\hline Accol & $12(20 \%)$ & $7(12 \%)$ & $5(8 \%)$ & $35(59 \%)$ \\
\hline
\end{tabular}

\section{Exhibit 1.}

Capital Budgeting Methods in Use

Figure 5 shows that $10 \%$ of the firms sometimes use net present value, $24 \%$ often, $42 \%$ always use NPV, while $24 \%$ of firms never use net present value.
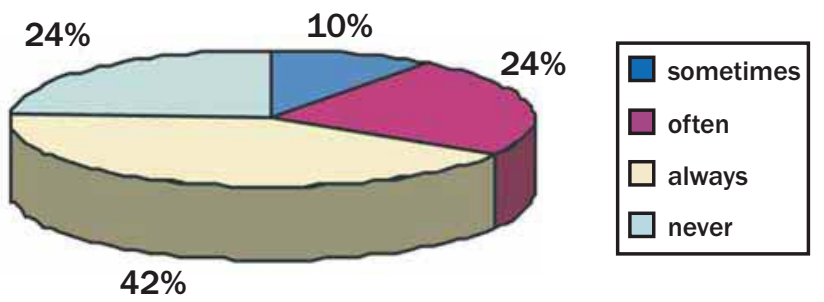

Figure 5.

Use of NPV
A survey by Farragher, Kleiman and Sahu (1999) of 128 American companies showed that $78 \%$ use net present value. Graham and Harvey (2001) surveyed 392 CFOs and found that $74,93 \%$ use net present value. European surveys show different results. For example, Drury and Tayles (1996), in their survey of 278 firms in Great Britain, found that 43\% of firms use net present value. Sandahl i Sjögren (2003), in their survey of 128 firms in Sweden, found that $52 \%$ of firms use net present value. Lazaridis (2004), found that just 11,39\% of 56 firms in Cyprus use net present value for project evaluation.

Figure 6 shows that $10 \%$ of the firms sometimes use internal rate of return (IRR), 12\% use IRR often, 59\% of firms always use internal rate of return, while $19 \%$ of firms never use internal rate of return for project evaluation.

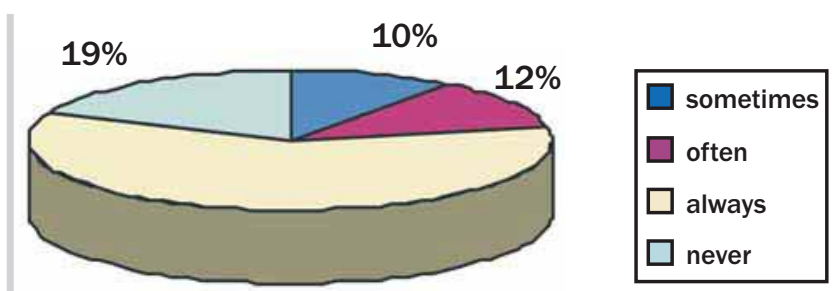

$59 \%$

Figure 6.

Use of Internal Rate of Return for project evaluation

Farragher, Kleiman and Sahu (1999) found that $80 \%$ of U.S. firms use internal rate of return, and Graham and Harvey (2001) found that 75,61\% of the firms use IRR. Drury and Tayles (1996) found that in Great Britain 57\% of the firms use IRR. In Sweden $23 \%$ of the firms use IRR according to Sandahl and Sjögren (2003), and according to Lazaridis (2004), in Cyprus just 8,86\% of the firms use IRR.

Figure 7 shows that payback period is sometimes used in $8 \%$ of the firms, $19 \%$ often, $56 \%$ always, while $17 \%$ of the firms never use payback period when evaluating investment projects. 


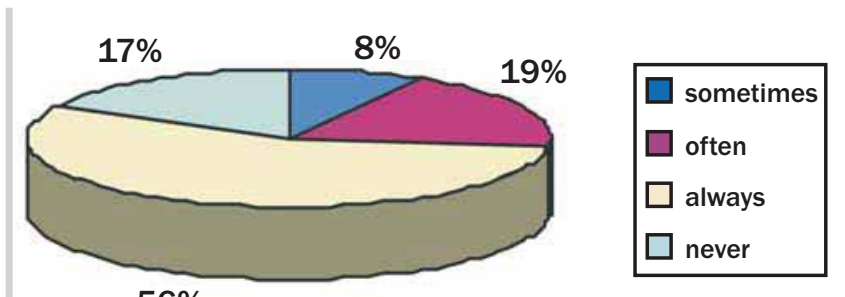

Figure 7.

Use of payback period for project evaluation

Farragher, Kleiman and Sahu (1999) found that $52 \%$ of U.S. firms use payback period, and Graham and Harvey (2001) found that $56,74 \%$ of the firms use payback period. In Sweden, $78 \%$ of the firms use payback period (Sandahl and Sjögren, 2003). In Great Britain 63\% of the firms always use payback period (Drury and Tayles, 1996), and in Cyprus 36,71\% of the firms use payback period (Lazaridis, 2004).

Figure 8 shows that $24 \%$ of the firms sometimes use discounted payback period, $14 \%$ often, $27 \%$ always, while $36 \%$ never use discounted payback period when evaluating investment projects.
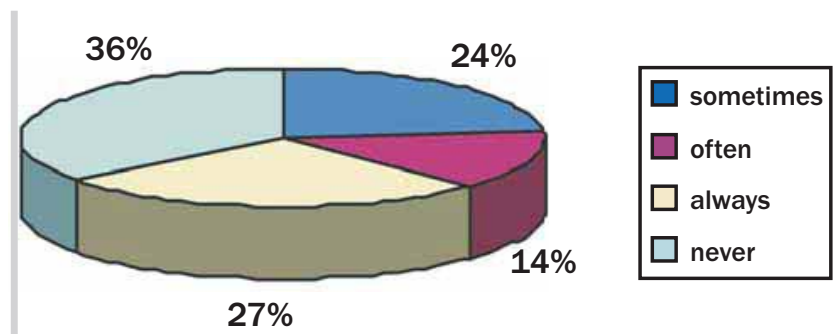

Figure 8.

Use of discounted payback period

Graham and Harvey (2001) found that 29,45\% of American companies always use discounted payback period. In Great Britain $42 \%$ of the firms always use discounted payback period (Drury and Tayles, 1996).

Figure 9 shows that $8 \%$ of the firms sometimes use profitability index, $24 \%$ often, $22 \%$ always, while $46 \%$ never use profitability index.

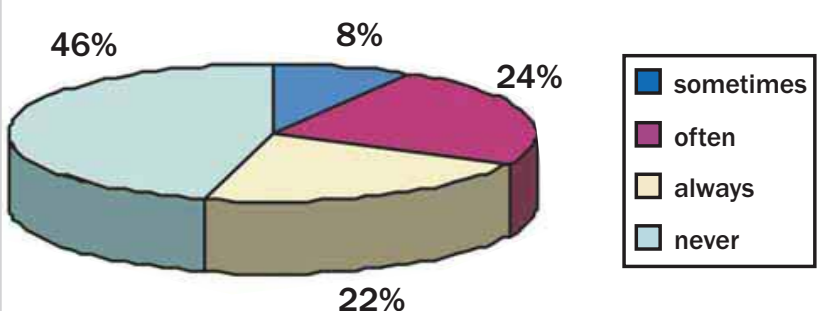

Figure 9.

Use of profitability index
When evaluating investment projects, $22 \%$ of the firms sometimes use an annuity method, 10\% often, 10\% always, while 58\% never use an annuity method (Figure 10).

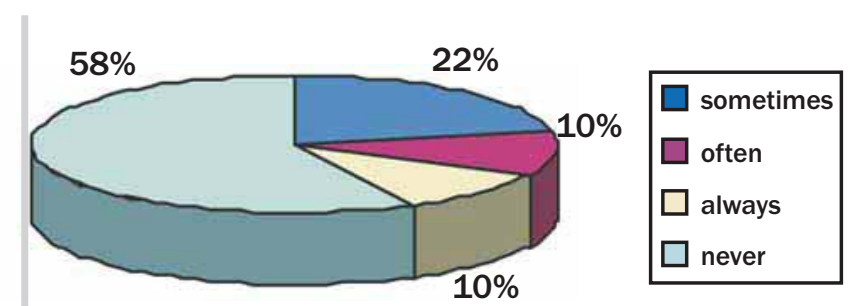

\section{Figure 10.}

Use of annuity method

Figure 11 shows that $25 \%$ of the firms sometimes use modified internal rate of return, $5 \%$ often, $3 \%$ always, while $66 \%$ of the firms never use MIRR when evaluating investment projects.

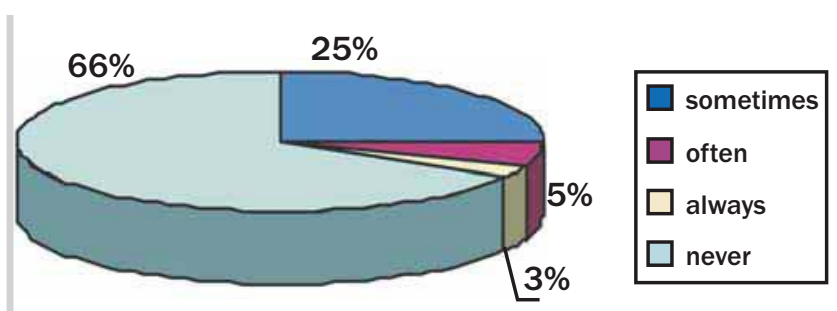

\section{Figure11.}

\section{Use of Modified Internal Rate of Return}

Additional results of the survey show that $20 \%$ of the firms sometimes use accounting rate of return, 12\% use it often, $8 \%$ always, while $59 \%$ of the firms never use accounting rate of return when evaluating investment projects. According to Farragher, Kleiman and Sahu (1999) 34\% of 128 U.S. companies use accounting rate of return, and Graham and Harvey (2001) found that $20,29 \%$ of 392 American companies use accounting rate of return. In Sweden, $21 \%$ of the firms use accounting rate of return.

After indicating capital budgeting methods used when evaluating investment projects, the respondents had to select the two most important for decision-making. Results shows that for $22 \%$ of the firms the two most important capital budgeting methods are NPV and IRR, for $24 \%$ of the firms these are IRR and payback period, and for $5 \%$ of the firms the two most important methods are payback period and annuity method. For $3 \%$ of the firms these are payback period and NPV, payback period and accounting rate of return, and payback period and profitability index. Also, for 3\% of the firms the most important are payback period, NPV and IRR, and discounted payback period and IRR. 15\% of the firms use other methods. These include NPV and discounted payback period, IRR and accounting rate of return, IRR and MIRR, and NPV and profitability index. For 
one firm the most important factors are the opinions of the financial manager and manager for development. 17\% of the firms did not answer the question. The most important capital budgeting methods are summarized below in Figure 12.

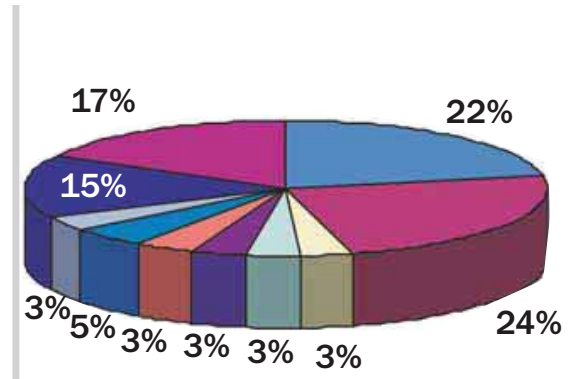

Figure 12.

The most important capital budgeting methods

\subsection{Cost of Capital and Cash flow estimation}

Another area of interest was the cost of capital and cash flow estimation. The survey showed that 45 (76\%) of the firms estimate the cost of capital, 8 (14\%) do not estimate, while 6 (10\%) did not answer (Figure 13).

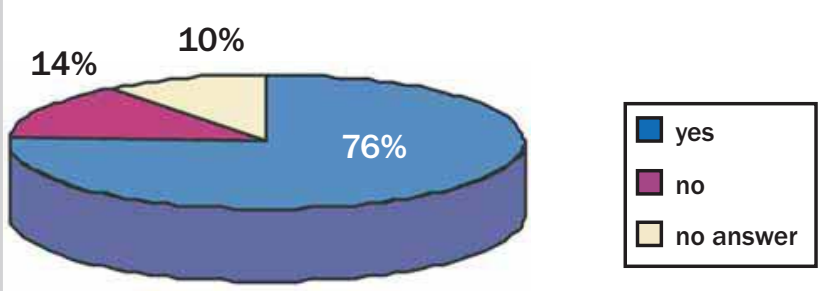

Figure13.

Do you estimate cost of capital

As presented in Figure 14, of the 45 firms that estimate the cost of capital, $40 \%$ use a cost of capital that is determined by "investor's required return", 9\% use the capital asset pricing

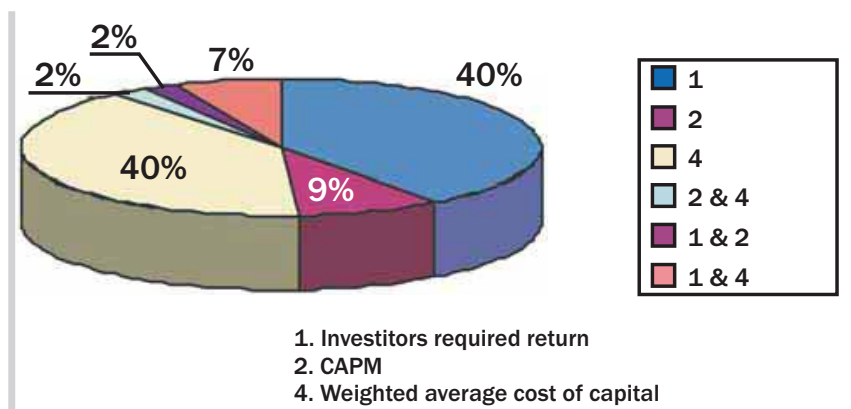

Figure 14.

How firms calculate the cost of capital

model (CAPM), 40\% determine the cost of capital as weighted average cost of capital, 2\% use CAPM and weighted average cost of capital, 2\% use "investor's required return" and CAPM, and $7 \%$ use "investor's required return" and weighted average cost of capital. None of the firms use Gordon's model (dividend discount model) when calculating the cost of capital.

Farragher and Kleiman (1999) found that 57\% of the American companies surveyed use the CAPM. Graham and Harvey (2001) found that 73,5\% of respondents always or almost always use the CAPM when calculating the cost of equity capital, 34,29\% use CAPM but including some extra «risk factors», 15,74\% use Gordon's model, and 13,93\% use investor's required return.

Of the 59 firms that participated in the survey, $81 \%$ estimate project cash flows, while 19\% do not. Table 2 presents different ways of project cash flow estimation. $23 \%$ of the firms form project cash flows using a sales forecast method, $8 \%$ use an expenditure rate method, $4 \%$ use only scenario analysis, $4 \%$ form cash flows using a sales forecast method and master budget techniques, 6\% use only master budget techniques, $8 \%$ form cash flows using an expenditure rate method and sales forecast method, $4 \%$ use a sales forecast method and profit models, $6 \%$ use a sales forecast and percentage of sales meth-
1. Expenditure rate method
2. Sales forecast

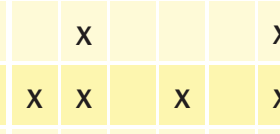
$x \quad x$

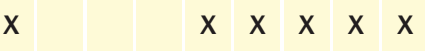
3. $\%$ of sales
4. Master budget techniques
$\mathrm{x} \times$

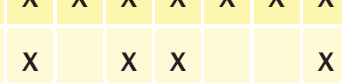
$x \quad x \quad x$

\section{Profit models}
6. Trend analysis
7. Scenario analysis
8. Budget with "ø" base
$x \times x$
$\mathrm{x}$

\begin{tabular}{|l|l|l}
$x$ & $x$ & $x$ \\
$x$ & $x$ & $x$
\end{tabular}
$x \quad x \quad x$
$x$
$x \quad x \quad x$

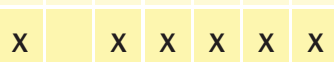
TOTAL
$\mathrm{x}$
$\mathrm{x} \times$
$\mathrm{X}$

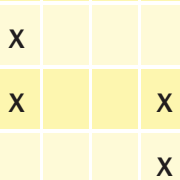
$x$
$\mathrm{x}$

Table 2.

How do you form project cash flows 
od, 4\% use a sales forecast method and trend analysis, while the remaining 33\% use methods shown in Table 2.

Figure 15 shows departmental responsibility for project cash flows methodology and forecasting. In 22 of the firms (37\%) the financial planning department is responsible for cash flows and forecasting, in 8 (14\%) the business-planning department is responsible, in 3\% the financial planning and businessplanning departments are responsible, in 21 firms (36\%) other departments are responsible, while $10 \%$ of the firms did not answer the question.

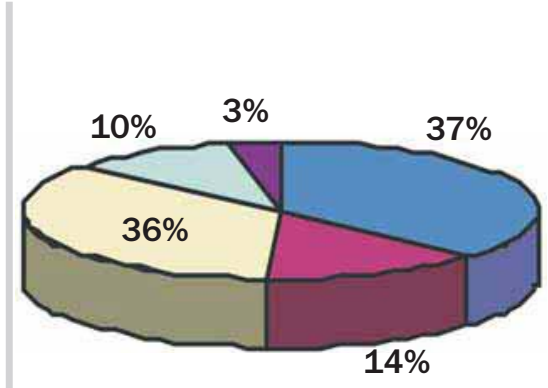

Figure 15.

Which department is responsible for cash

$\square$ financial planning department

$\square$ bussiness planning department

$\square$ some other department

$\square$ no answer

financial planning \& bussiness planning departments

flow forming and forecasting

Figure 16 presents the results for the remaining 21 firms (36\%) that have a variety of other departments responsible for cash flow methodology and forecasting. In 8 of the remaining firms (38\%) the controlling department is responsible for cash flow forming and forecasting, in 14\% the finance department, in $10 \%$ the department for planning and analysis, and for the remaining 38\% other departments are responsible, such as marketing and controlling, accounting, finance and accounting, or the finance and controlling departments.

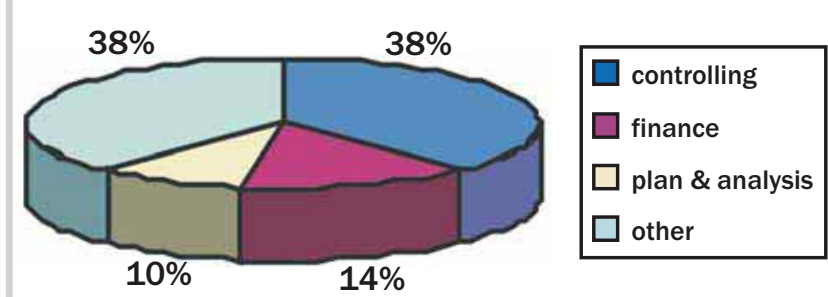

Figure 16.

Other departments responsible for cash flows forming and forecasting

Regarding opportunity costs, $46 \%$ of the firms include opportunity costs in project cash flows, $41 \%$ do not, while $14 \%$ did not answer the question (Figure 17).

Figure 18 shows that $73 \%$ of the firms include interest expenses in project cash flows, 15\% of the firms do not, while $12 \%$ did not answer.

The results of the survey show that $41 \%$ of the firms include inflation in project cash flows, $47 \%$ do not, while $12 \%$ did not answer (Figure 19)

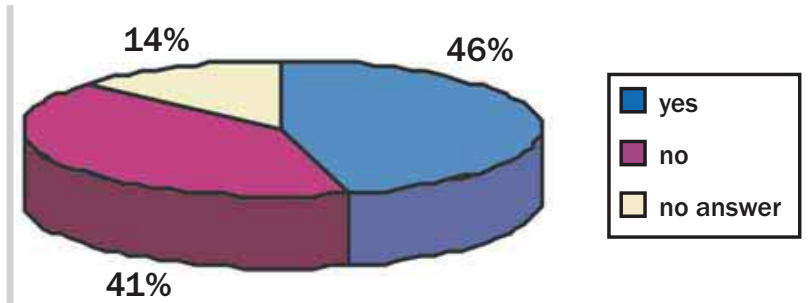

Figure 17.

Do you include opportunity costs in project cash flows

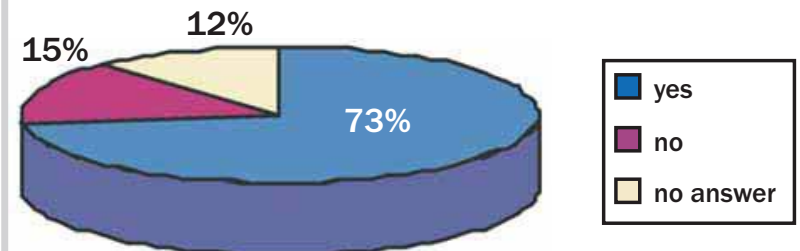

Figure 18.

Do you include interest expense in project cash flows

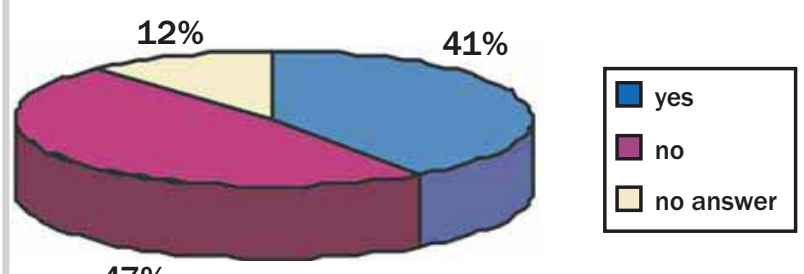

Figure 19.

Do you include inflation in project cash flows

Figure 20 shows that $47 \%$ of the firms analyse the interdependence of a project and firm cash flows, 39\% do not, while $14 \%$ did not answer. Of the 28 firms (47\%) which analyse the interdependence of a project and firm cash flows, 50\% marked the technique they use for analysis. Techniques used to estimate interdependence of a project and firm cash flows include consolidation of the projected financial statement, present value of cash flows, comparing balance sheets through direct and indirect cash flow methods, simulation, and orders profit reports.

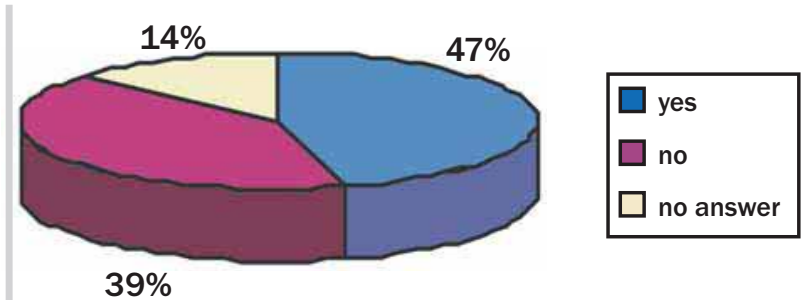

Figure 20.

Do you analyse the interdependence of a project and firm cash flows 


\subsection{Risk analysis}

Another area of interest in our survey was to determine whether or not firms estimate the project risk and which techniques for assessing risk are used. Regarding project risk analysis, 43 of the firms (73\%) estimate the project risk, 9 of the firms (15\%) do not, while 7 of the firms (12\%) did not answer the question (Figure 21).

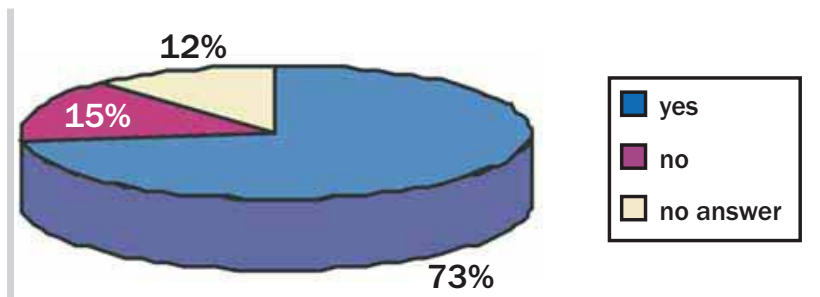

Figure 21.

Do you estimate the project risk

Of the 43 firms that estimate project risk, 21 (49\%) use sensitivity analysis for risk evaluation, 3 (7\%) use scenario analysis, 8 (19\%) use simulation, 6 (14\%) use sensitivity analysis and scenario analysis, 2 (5\%) sensitivity analysis, scenario analysis and decision tree analysis, 2 (5\%) use scenario analysis and simulation, one firm (2\%) uses sensitivity analysis, decision tree and simulation, while one firm does not use any specific risk analysis technique (Figure 22).

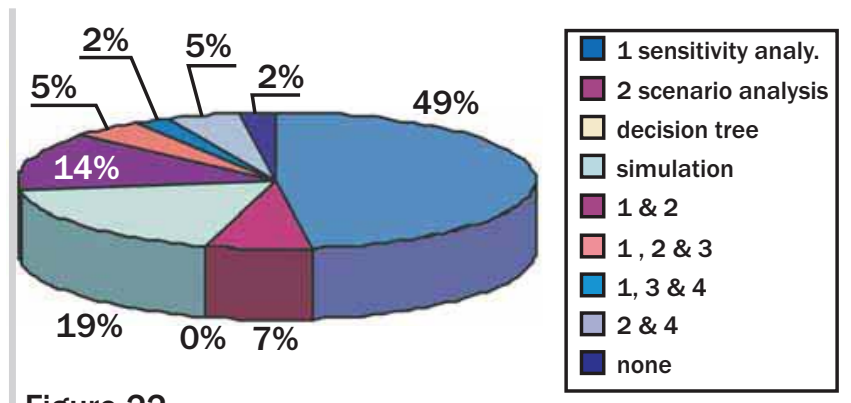

Figure 22.

Which methods do you use for risk evaluation

Regarding market risk, 34 of the firms (58\%) assess the market risk, 17 (29\%) do not, while 8 of the firms (14\%) did not answer (Figure 23). Of the 34 firms that assess market risk, 20 (59\%) marked the method they use. Among the market risk assessment methods used, 3 of the firms used scenario analysis, 4 used simulation, 4 used market analysis, and the remaining 9 firms a combination of sensitivity analysis, long-term projections correlation, forecasting methods, trend analysis and market shares, etc.

Figure 24 shows that 36 of the firms (61\%) assess project risk for the firm, 15 (25\%) do not, while 8 of the firms (14\%) did not answer.

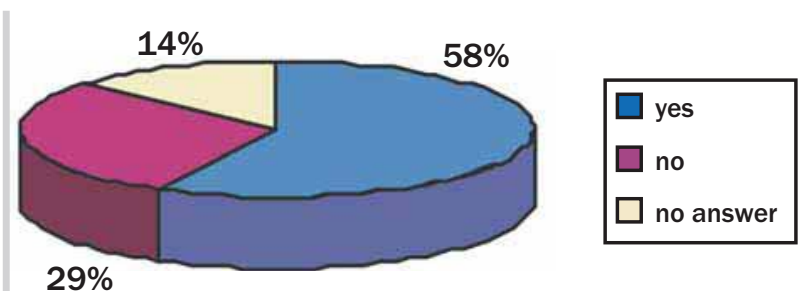

Figure 23.

Do you assess market risk

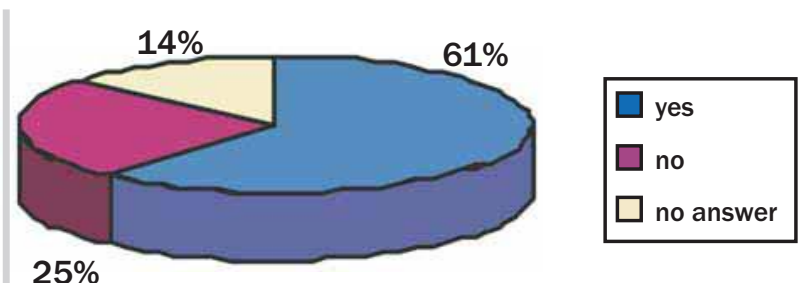

Figure 24.

Do you assess project risk for the firm

Of the 36 respondents that assess project risk, 21 (58\%) marked the technique used (Figure 25). 4 of the firms (19\%) use simulation, 2 (10\%) use sensitivity analysis, 3 (14\%) scenario analysis, 1 (5\%) uses sensitivity analysis and simulation, while 2 (10\%) adjust WACC. The remaining 9 firms (43\%) gave different answers, including SWOT analysis, IRR, all risk analysis, risk reviews for important projects, etc.

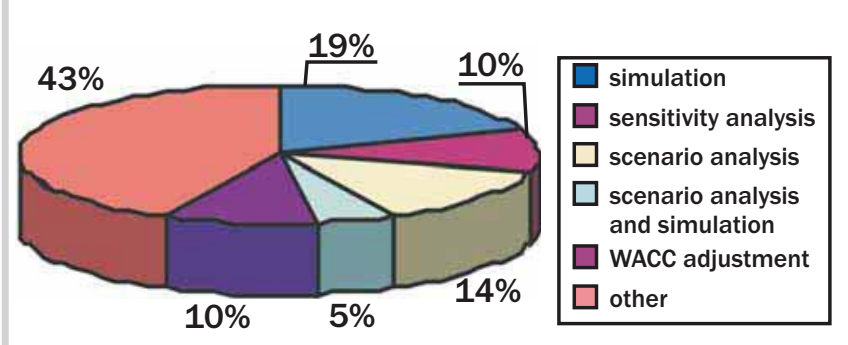

Figure 25.

How do you evaluate the impact of the project risk on the firm

There are various methods of incorporating risk into a capital-budgeting analysis, including adjusting the payback period, using a risk-adjusted discount rate, adjusting cash flows, and calculating certainty equivalents for the cash flows (Shapiro, 2005). Of the 59 sampling firms, 25 (42\%) adjust the discount rate for risk or use a risk-adjusted discount rate, 17 (29\%) calculate certainty equivalents for cash flows, while 17 (29\%) did not answer (Figure 26). In 19 of the firms (32\%), project risk is ranked by type; 32 firms (54\%) do not rank risk by type, while 8 of the firms (14\%) did not answer.

According to Farragher, Kleiman and Sahu (1999), 63\% of U.S. firms use a risk-adjusted discount rate, and 37\% use certainty equivalents. The survey of Graham and Harvey (2001) 
showed that $51 \%$ of the companies always or almost always adjust the discount rate for risk.

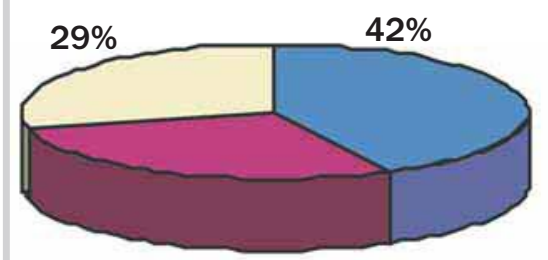

$29 \%$

Figure 26.

How do you incorporate relevant risk into a capital-budgeting analysis

\subsection{Strategic projects}

Finally, we explored the procedures of strategic projects analysis. We found that 51 firms (86\%) analyse strategic projects. Of the 51 firms that analyse strategic projects, 29 (57\%) use traditional cash flow analysis, 5 (10\%) use comparisons with similar assets, 4 (8\%) use some other way (e.g., continuous analysis iteration), 12 (24\%) use traditional cash flow analysis and comparison with similar assets, and only 1 firm (2\%) uses traditional cash flow analysis and binomial option pricing (Figure 27).

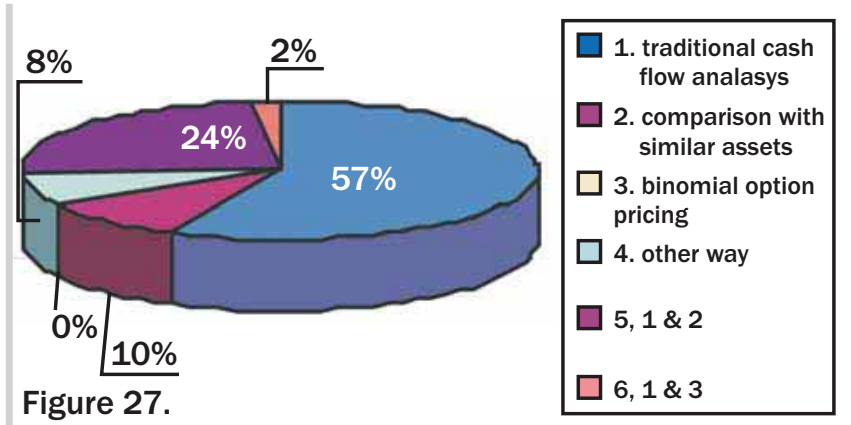

Procedure of the strategic project analysis

Additionally, we found that only 9 of the firms (15\%) use a decision tree for scenario analysis modification, 41 (69\%) do not use strategic option analysis, while 9 of the firms (15\%) did not answer. Figure 28 shows that 15 of the firms (25\%) use strategic options analysis, 36 (61\%) do not analyse strategic options, while 8 of the firms (14\%) did not answer.

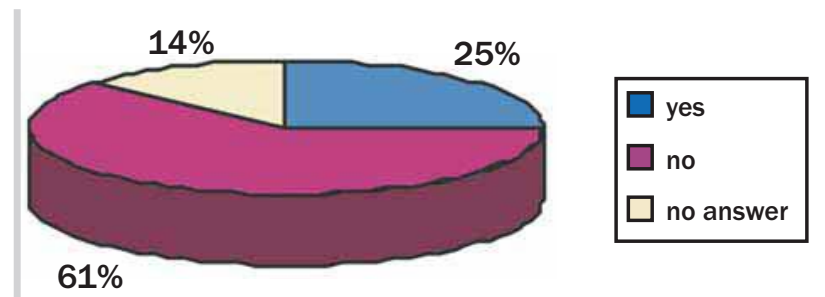

Figure 28.

Do you analyse strategic options

Of the 15 firms that analyse strategic options, only 3 indicated that they estimate the strategic options value. This is $5 \%$ of the entire sample of 59 firms. The last question was, "How do you estimate strategic option value?" We received two answers. One of the firms uses a «standard procedure», while the other uses a «binomial option pricing model». Considering that a «standard procedure» for option pricing does not exist, the only relevant answer is «binomial option pricing». We can thus conclude that only one firm (1,69\% of the sample) estimates strategic options value.

\section{Conclusion}

This paper has presented the findings of a mail survey of capital budgeting practices sent to a selected sample of 234 Croatian firms and compared the results with similar studies in the USA, UK, Sweden, and other European countries. The purpose of this study was to determine the present application of quantitative capital budgeting methods, cost of capital and cash flow estimation, risk analysis and application of the real options approach. The results of the survey show that the responding Croatian firms employ currently available capital budgeting methods less extensively than firms in other countries (e.g., USA) when evaluating long-term investment projects. Specifically, 59 percent of Croatian firms always use IRR, 56 percent always use payback period, and 42 percent always use NPV. For firms in the U.S., 75-80\% use IRR and $75-78 \%$ use NPV.

Results also show that for 22 percent of the sample firms the two most important capital budgeting methods are NPV and IRR, and for $24 \%$ of the sample firms these are IRR and payback period. The results of the survey show that 45 of the investigated firms (76\%) estimate cost of capital. $40 \%$ use a cost of capital that is determined by "investor's required return", $9 \%$ use the CAPM, and $40 \%$ determine the cost of capital as WACC. The results of the survey show that of the 59 firms that participated in the survey, $81 \%$ estimate project cash flows, and $73 \%$ estimate project risk. $42 \%$ of the firms use a risk-adjusted discount rate, and $29 \%$ calculate certainty equivalents for cash flows. We found that 51 firms (86\%) analyse strategic projects and that 15 of the firms (25\%) analyse strategic options. Of the 15 firms that analyse strategic or real options, only one firm estimates the strategic or real options value using a binomial option pricing model.

In conclusion, Croatian firms, for the most part, could use current capital budgeting methods more extensively when evaluating investment projects. The lack of use may be due to a lack of familiarity with such methods. These findings indicate a need in education and training for the managers of firms in the area of capital budgeting. 


\section{References}

Drury, Colin and Mike Tayles, «UK Capital Budgeting Practices: Some Additional Survey Evidence», European Journal of Finance (2), (1996): 371-388.

Farragher, Edward J., Robert T. Kleiman and Anandi P. Sahu, "Current Capital Investment Practices», Engineering Economist (44), 2, (1999): 137-150.

Graham, John R. and Campbell R. Harvey, «The Theory and Practice of Corporate Finance: Evidence from the Field", Journal of Financial Economics (60), 2-3, (2001): 187-243

Lazaridis, Ioannis T., «Capital Budgeting Practices: A Survey in the Firms in Cyprus», Journal of Small Business Management (42), 4, (2004): 427-433.

Sandahl, Gert and Stefan Sjögren, «Capital Budgeting Methods among Sweden's Largest Groups of Companies. The State of the Art and Comparison with Earlier Studies», International Journal of production Economics (84), 1, (2003): 51-69.

Shapiro, Alan C., Capital Budgeting and Investment Analysis, New Jersey: Prentice Hall, 2005. (1st ed.). 